Department of Histology,

Fac. of Vet. Med. Sues Canal Univ. Ismaillia.

\title{
DISTRIBUTION OF ANP-PRODUCING CELLS IN THE HEART OF OREOCHROMIS NILOTICUS AN ULTRASTRUCTURAL AND IMMUNOHISTOCHEMICAL STUDY
}

(With 9 Figures)

\section{By}

H. E. MAREI

(Received at 16/6/1996)

\section{توزيع الخلابِ المفرزه لهرمون ANP فى قتب أسماك البلطى النبلى: دراسة بواسطة الميكروسكوب الاكترونى ودراسة مناعة كيمباء الاستجه السيه

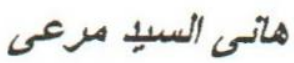

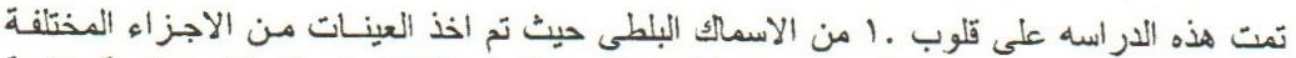

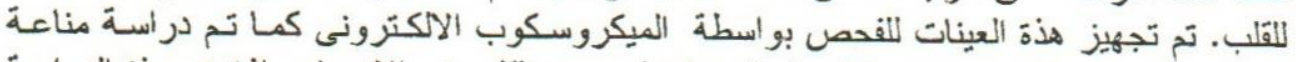

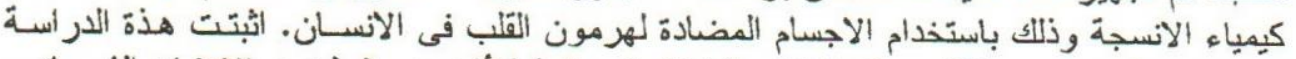

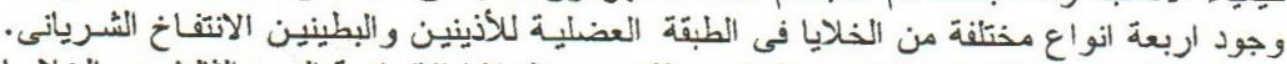

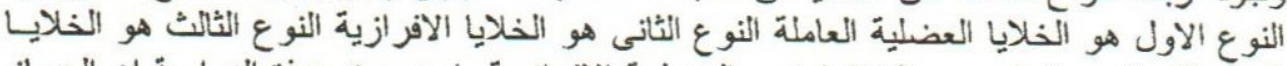

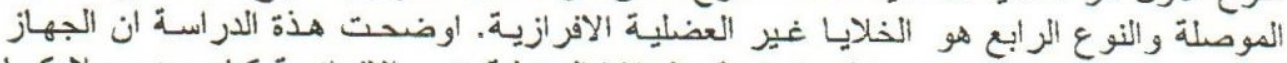

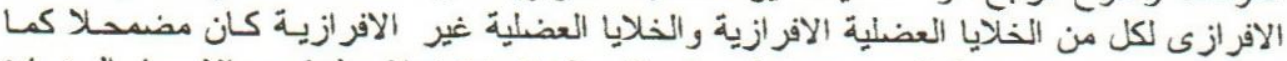
أعطت الحبيبات الافر ازية الموجودة داخل سيتوبلازم الخلايـا تفاعلا سلبيا ميع الاجسام المضـادة

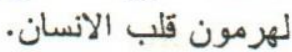

\section{SUMMARY}

The heart of the Oreochromis niloticus has been studied ultrastructurally and immunohistochemically in order to describe the distribution of ANPproducing cells, and the nature of the putative fish cardiac hormone. Utrastructural examination of the bulbus arteriosus, atrial and ventricular mycoardial layer has disclosed the presence of at least four cell types:1) 
working myocardiocytes; 2) granules-containing contractile cells; 3) Purkinje conduction cells and 4) granules-containing non-contractile cells. The granules-containing contractile cells were observed as an isolated endocrine units randomly scattered throughout the different myocardial regions. In comparison to other mammalian species, the secretory activity of both the granules-containing contractile cells and the conduction cells was illdeveloped. Negative anti- human ANP immunoreactivity was demonstrated for all cell types. In conclusion, the heart of the Oreochromis niloticus seemed to have a less pronounced ANP secretory activity. Moreover, the nature of the fish cardiac hormone was apparently different form that of the human ANP.

Key words: ANP; Oreochromis nilticus, heart; ultrastructure and immunohistochemistry.

\section{INTRODUCTION}

Atrial natriuretic peptide is a novel polypeptide hormone secreted primarily from the heart. Several studies had concluded that the greater majority of the ANP-producing cells were concentrated mainly within the artial wall, specially in the right atrium (ACKERMANN et al., 1986). However, ventricular and Purkinje ANP-producing cells were also reported (FORSSMANN, 1986). In a previous report, the distribution of these cells within the different regions of the camel's heart have been studied (MAREI, 1994). In another study attention have paid to the avian endocrine heart (MAREI, 1994). In another study attention have been paid to the avian endocrine heart (MAREI and OSMAN, 1995). The results of both studies were conflicting. In camels, ANP-producing cells were well developed with a prominent secretory activity. On the contrary, avian ANP-producing cells were infrequently recognized.

Several factors might contribute to such differences of which the phylogenetic matter and the complexity of the cardiovascular system appeared to have a crucial role. With increasing complexity of the cardiovascular system, there seem to be a phylogenetic trend towards concentration of ANP-producing cells within the atrial wall (CHAPEAU et al., (1985).

Data pertaining to the density and distribution of the ANP-producing cells in the fish heart is still lacking. Moreover, the possible role of the putative 
fish cardiac hormone as a regulator to fish body fluid and electrolytes homeostasis is not yet determined.

Therefore, the goal of this study was to study the density and distribution of ANP-producing cells in the different regions of Oreochromis niloticus heart. A second aim was to determine the relation between the putative fish cardiac hormone and the human cardiac hormone as a representative to the mammalian cardiac hormone.

\section{MATERIALS and METHODS}

Ten hearts were collected from apparently healthy Oreochromis niloticus. Samples were taken from the different heart regions including the bulbus arteriosus, atrium and ventricles. They were fixed in $2.5 \%$ glutaraldehyde in $0.1 \mathrm{M}$ cacodylate buffer at $\mathrm{PH} 7.4$ for 12 hours. They were washed in $0.1 \mathrm{M}$ cacodylate buffer, post fixed in $1 \%$ osmium tetroxide in $0.1 \mathrm{M}$ sodium cacodylate for 1 hours, washed in buffer again and dehydrated in a graded series of ethanol. They were then infiltrated with propylene oxide and embedded in poly/bed 812 resin. Ultrathin section were cut using glass knives and placed on 200-mesh uncoated copper grids. The sections were double stained with uranyl acetate and lead citrate and examined with transmission electron microscope operating at $80 \mathrm{KV}$.

For immunohistochemistry, the fixed tissues were embedded in L.R. white resin. Ultrathin golden sections were cut and placed 200-mesh nickel grids previously coated with formvar for 1 second. The sections were first treated with $10 \%$ heat inactivated normal rabbit serum in Tris buffer for 30 minutes. They were then incubated with the primary antibody (Goat anti- human ANP) diluted to $1: 500$ to $1: 1000$ in $0.01 \mathrm{M}$ phosphate buffer at $\mathrm{pH} 7.4$ containing $0.15 \mathrm{M} \mathrm{Na} \mathrm{Cl}, 0.3 \% \mathrm{BSA}, 0.1 \%$ triton X 100, 0.001 M EDETA and $0.1 \%$ sodium azide for 16 hours at $25 \mathrm{C}$. The sections were then washed with the same dilution buffer then with distilled water. After drying, they were stained with low concentration of uranyl acetate $(0.5 \%)$ for 30 seconds, and with lead citrate for 5 minutes. For controls the primary antibody was replaced by buffer.

\section{RESULTS}

The light microscopic examination of the atrial, bulbus arteriosus, and ventricular wall has revealed the trabecular nature of the myocardiocytes forming the heart wall which were clearly evident in the bulbus and atrial wall 
than in the ventricles. The endocrine nature of the myocardiocytes was not evident at the light microscopic level.

Ultrastructural examination of the bulbus arteriosus, atrial and ventricular myocardial layer had disclosed the presence of at least 4 cell types: 1) Working myocardiocytes; 2) Granules-containing contractile cells, 3) Purkinje conduction cells and 4) Granules-containing non-contractile cells.

The working cells constituted the main cell types, their ultrastructural features were, to a large extent, similar to those previously described in other mammalian species. They had an ill-developed secretory apparatus with an entire absence of any secretory granules within their cytoplasm. Other organelles including mitochondria, SER, and lysosomes were quite similar to mammalian working myocardiocytes (Fig. 1).

The granules contractile cells constituted the second cell type, and represented fewer percentage of the cells forming atrial and ventricular myocardium. They were mostly observed as an isolated endocrine units randomly scattered throughout the different mycoardial regions. their ultrastructural features were, to large extent, similar to the working cells. In addition, a comparatively ill-developed secretory apparatus was recognized within their cytoplasm. It was composed of scarce tubules of rER, a prominent Golgi complex which were encountered mainly in the perinuclear regions (Fig.2). Within the perinuclear regions, Golgi saccules were associated with few progranules, and mature secretory granules (Fig. 2). However, migration of these granules to the interfibrillar (Fig.3) and subsarcolemmal spaces (Fig.4) was apparent in some cells. The mature secretory granules were ovoid to spherical in shape, mambrane-bound, electron dense granules, with a diameter of 90 to $100 \mathrm{~nm}$. Their electrondense matrix was separated from the surrounding membane through a welldefined electron-lucent area (Fig. 2, 3, 4). The progranules were slightly smaller in size with less electron-dense, and were associated with Golgi cisternae. Although migration of the mature secretory granules to the subsarcolemmal regions was observed in many specimens. No fusion or exocytosis through the sarcolemma was recognized in any of the examined specimens.

The third cell type was the Purkinje conduction cells, their ultrastuctural criteria were similar to mammalian conduction cells. These cells were recognized mainly among the ventricular mycardiocytes. The secretory nature of these cells was ill-developed, and few mature secretory granules were recognized in their cytoplasm. Their mitochondrial population was characterized by few cristae (Fig. 5). 
The fourth cell type that were identified among the cardiocytes forming the atrial and ventricular wall was the granules-containing non-contractile cells. These cells were recognized either singly or in groups. Ultrastructurally, each of these cells had an oviod centrally located nucleus with a prominent nucleolus and dispersed chromatin (Fig. 6). There was a complete absence of any contractile materials within their cytoplasm. They were characterized by a well-developed secretory apparatus composed of a clearly defined rough endoplasmic tubules, free ribosomes and prominent Golgi complex. Much of their cytoplasm was occupied by a tremendous number of mature secretory granules (Fig. 6,7). They were membrane bound, spherical to oval in shape, with a diameter of $100-400 \mathrm{~nm}$. Morphologically, tow types of mature secretory granules were differentiated (Fig. 7), an electron-dense granules, and a comparatively electron-lucent one. Fusion between adjacent granules was evident in some cells, and some granules were seem to be ruptured releasing their contents into the cytoplasm (Fig. 7) Some cells appeared degranulated with their cytoplasm contained few granules and many clear vesicular structures (Fig. 8).

Treating the sections with the anti- human ANP had revealed a negative ANP-immunoreactivity within the matrix of the mature secretory granules and the progranules (Fig. 9).

\section{DISCUSSION}

ANP-producing cells are a group of highly specialized cells recognized mainly among the cardiocytes forming the atrial and ventricular wall. From previous studies, the distribution of these cells within the different mammalian and submammalian heart regions was clearly different. In human heart, these cells were concentrated mainly among the cells forming the atrial wall, especially the right atrium (Ackermann et al., Currie et $\underline{\text { al. }}$, 1983.,

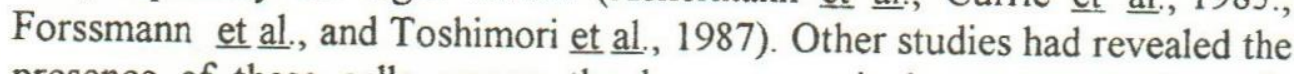
presence of these cells among the human ventricular and Purkinje cells (Chapeau et al., 1985; Gobel et $\underline{\text { al. }}$, 1986; Back et al., 1986). In camels, these cells were concentrated mainly among the cardiocytes forming the right and left atrial wall. However, right ventricular, interventricular, and Purkinje ANP-producing cells were also recognized (Narei, 1994). In invertebrate heart, ANP-producing cells were found exclusively in neuroendocrine nerve endings of the cardiac atrium. No ANP-immunoreactivity was present in cardiac myocytes (Reinecke et al., 1987a and Nehls et al., 1985). In this study, a completely different feature of ANP-producing cells is their 
distribution. ANP-producing cells were recognized as a separate endocrine units randomly scattered among the cardiocytes forming the different heart regions. This unique distribution was similar to our previous findings concerning the distribution of these cells in the chicken's heart (Marei and Osman, 1995). Beside the clear similarity in the distribution of ANPproducing cells in the avian and fish hearts, the secretory activity of these cells in both species was not pronounced like those in other mammalian species.

The granules-containing cells were equally recognized among the cardiocytes forming the atrial and ventricular wall. This observation disagreed with the assumption given by Chapeau et al. (1985) that in lower vertebrate classes such as fish, ANP-producing cells occurred in considerable number in the ventricle. However, the present results were consistent with those of De Bold and Salerno (1983) that cardiac hormone appears to have an important functional role in the higher vertebrate classes than in the lower vertebrate.

In the present study the ultrastructural features of the fish ANP-producing cells were similar to those of the avian heart. However, in comparison to avian species fish myoendocrine cells were characterized by smaller secretory granules, their diameter ranged between 90-100 $\mathrm{nm}$. In other mammalian species including the human beings and camels the secrtory activity of the myocardiocytes was more pronounced than those described for avian and fish species. The mammalian myoendocrine cells were recognized mainly through their tremendous number of mature secretory granules which were concentrated mainly wihtin the perinuclear regions. However, insinuation of these granules in the interfibrillar and subsarcolemmal regions was common.

Based on the secretory activity of these cells, 3 cell types were recognized: 1) typical myoendocrine cells that had the highest number of mature secretory granules within their cytoplasm, 2) transitory cells which had a comparatively limited number of mature secretory granules and less pronounced secretory activity, and 3) working cells with an entire absence of any secretory granules in their cytoplasm (Marel, 1994). At the morphological level, it was not clear whether the transitory cells represent a degranulated cells in response to certain condition that required the release of their hormonal contents. Or, they were genetically programmed to produce less hormone. In the light of the aforementioned results and the result obtained here, the phylogenetic matter seemed to have a crucial role. Therefore, within the fish heart as a representative to vertebrates, the less pronounced diversity in the secretory activity of the granules-containing 
cardiocytes could be observed as some kind of genetic programming for the production of less hormone. On the other hand the diverse secretory activity within the mammalian mycoendocrine cells could be attributed either to degranulation in response to hormonal need, or they were also genetically programmed to produce less amount of hormone. The constant feature of few mature secretory granule within the fish myoendocrine cells could eliminate the possibility of degranulation as a cause for the less pronounced secretory activity in fish myocardiocyte.

Treating the section with monoclonal antibody directed against the human ANP has disclosed a completely negative reactivity within the matrices of both the progranules and the mature secretory granules. These results were similar to those previously within the matrices of both the progranules and mature secretory granules. These results were similar to those previously reported for the avian heart (Marei and Osman, 1995) and might indicate a difference in the nature and amino acid sequence between fish and human cardiac hormone. On the other hand, the positive reaction within the granule matrix of the camel myoendocrine cells (Maeri, 1994) had suggested a similarity between the camel and human cardiac hormone, and aslo might indicate a difference in the nature and function of cardiac hormone between the mammalian and submammalian species.

Comparing the differences in distribution of ANP producing cells could also support the contention that cardiac hormone is of less or no important to fish species. Atrial wall stretch is the main inducer for the release of this hormone (ANDERSON et al., 1986 and BILDER et al., 1986). Therefore, the concentration of these cells among the atrial cardiocytes would logically help the effectiveness of the secretory cycle of the cardiac hormone. On the contrary, the random distribution of these cells among the cardiocytes forming fish heart and the ill-developed secretory activity within these cells would eliminate the stretch stimulus as a primary inducer for cardiac hormone release.

In addition to granules-containing myocardiocytes, numerous noncontractile granules-containing cells were also reported to exist among the cardiocytes forming the dipnoan fish heart. Such cells usually form a thick subendocardial layer in the auricle, but occasionally show single cells interposed among atrial working cells (SCHNERMANN, 1988). These findings agreed with those reported in the present study where we had observed similar cells among the Oreochromis niloticus cardiocytes. There was a close similarity in the morphological criteria of these granules and 
those of the catecholamine-containing secretory granules (BLOOM $\underline{\text { et }}$ al., 1961).

\section{REFERENCES}

Ackermann, D.M., Edwards, B.S., Wold, L.E., Burnette, J.C. (1986): Atrial natriuretic peptide, localization in the human heart. JAMA 256: 1048.

Anderson, J.V., Donckier, J., Mckenna, W.J., Bloom, S.R. (1986): The plasma release of atrial natriuretic peptide in man. Clin. Science, 71, 151-155.

Back, H., Stumpf, W.E., Ando, E., Nokihara, K., Forssmann, W.C. (1986): Immunocytochemical evidence for CDD/ANP-like peptides in strands of myoendocrine cells associated with the Ventricular Conduction System of the rat heart. Anat. Embryol 175: 223-226.

Bilder, G.E., Schofield, T.L., Blaine, E.H. (1986): Release of atrial natriuretic factor. Effects of repetitive stretch and tempreture. Am. J. physiol 251: F817-F821.

Bloom, G., Ostlund, E., Eiuler, V., Lishajko, U.S., Ritzen, F., Adams-Rat, M., J. (1961): Studies on catecholamine-containing granules of specific cells in cyclostome hearts. Acta. physio. Scan., 53 (Suppl 185), 1-34.

Chapeau, C., Gutkowska, J. Schiller, P.W., Milne, R.W., Thibault, G., Garcia, R., Genest, J., Cantin, M. (1985): Localization of immunoreactive synthetic atrial natriuretic factor (ANF) in the heart of various animal species. J. Histochem. Cytochem., 33, 541-550.

Currie, M.C., Geller, D.M., Cole, B.R., Boylan, J.G., YuSheng, W.,

Holmberg, S.W., Needleman, P. (1983): Bioactive Cardiac Substances:

Potent Vaso relaxant activity in mammalian atrial. Science 221: 71-73.

De Bold, A.J., Salerno, T.A. (1983): Natriuretic activity of extracts obtained from hearts of different species and from various rat tissues. Can. J. physiol. pharmacol., 61, 127-130.

Forssmann, W.G. (1986): Gardiac hormones. I. Review on the morphology, biochemistry and molecular biology of the endocrine heart. Eur. J. Clin. Invest., 16, 439-451.

Forssmann, W.G., Hock, D, Lottspeich, F., Henschen, A., Kreye, V., christmann, M., Metz, J., Carlquist, M., Mutt, V. (1983): The righ auricle of the heart is an endocrine organ. Cardiodilatin as a peptide hormone candidate. Anat Embryol 168: 307-313.

Gobel, J., Metz, J., Forssmann, W.G. (1986): Korrelationzwishen Myoendokrinen Zellen und peptideger Innervation. Verh. Anat. Ges., 80, 551-553. 
Marei, H. (1994): A histological approach on the myoendrine cells of the camel heart. ph. D Thesis, Fac. Vet. Med., Suez Canal Univ.

Marei, H. and A.H.K. Osman (1995): Ultrastrucural and immunohistochemical study of the chicken's endocrine heart. First International Conference on Electron Microscopy, September 13-15, Ismailia, Egypt.

Nehls, M., Reinecke, M., Lang, R.E. Forssmann, W.G. (1985): Histochemical and immunological evidence for a cardiodilatin-like substance in the snail neurocardiac axis. Proc-Natl Acad Sci USA 82: 7762-7766.

Reinecke, M., Betzler, A., Forssmann, W.G. (1987a): Immunocytochemistry of cardiac polypeptide homones (cardiodilatin/ atrial natriuretic polypeptide) in brain and hearts of Myxine glutinosa (cyclostomata). Histochemistry 86: 233-239.

Schnermann, D.W. (1988): Catecholamine-containing granules in cardiac chromaffin cells as compared with atrial granules. In Forssmann, W.G., Scheurmann, D.W. (eds). Functional Morphology of the endocrine heart. Steinkoff Verlag darmastdt Soringer-Verlag New York, pp. 5561.

Toshimori, H., Toshimori, K., Oura, C., Matsuo, H. (1987): Immunohistochemistry and immunocytochemistry of atrial natriuretic polypeptide in porcine heart. Histochemistry 86: 595-601.

\section{LEGENDS}

Fig. 1: Working myocardiocytes. Note nucleus (N), myofibrils (My), mitochondria $(\mathrm{M})$ and entire absence of any secretory activity in the perinuclear region X 10000 .

Fig. 2: Granules-containing conduction cells. Note nucleus $(N)$, myofibrils (My), and mature secretory granules (arrows) X 36000 .

Fig. 3: Granules-containing contractile cells. Note migration of mature secretory granules (arrow) to the interfibrillar space X 36000 .

Fig. 4: Granules-containing contractile cells showing migration of mature secretory granules (arrow) to subsarcolemmal space X 29000.

Fig. 5: C.S. in Purkinje-conduction cells. Note myofibrils (My), Golgi (G), mitochondria with few cristae (M) and mature secretory granules (arrows) X 19000. 
Fig. 6: Granules-containing non-contractile cells. Note nucleus (N), rER tubules (arrows) and mature secretory granules (arrowheads) X 12 000 .

Fig. 7: High magnification to fig. 6 Note tow types of secretory granules: electron-dense (arrow) and electron-lucent (arrowhead) type X 14 000.

Fig. 8: Degranulated granules-containing non-contractile cells. Note nucleus (N), and few mature secretory granules (arrows) X 14000.

Fig. 9: Ultrastructural immunohistochemical labeling of the storage of ANP in Oreochromis niloticus myoendocrine cells. Note negative reaction $X 72000$.

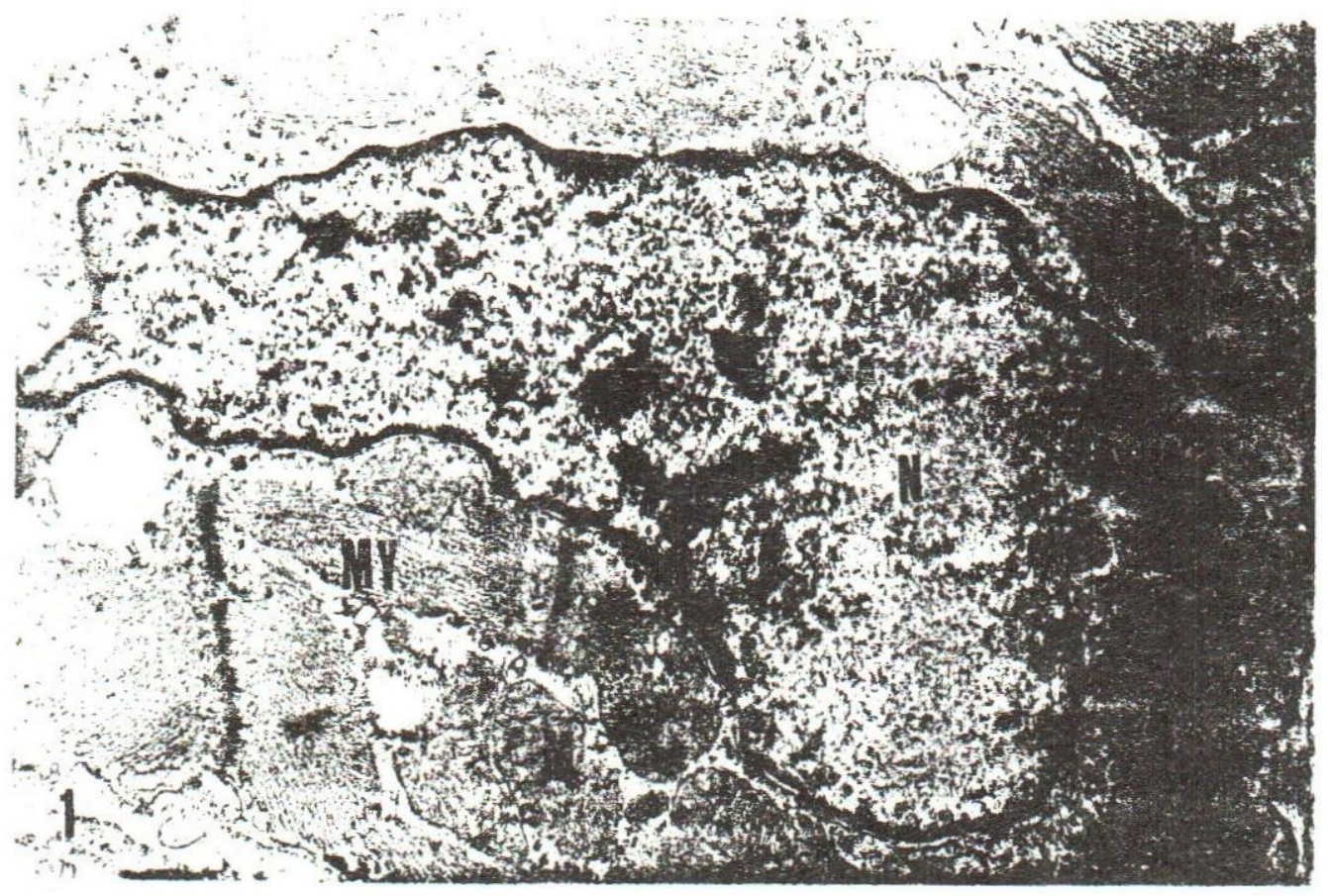



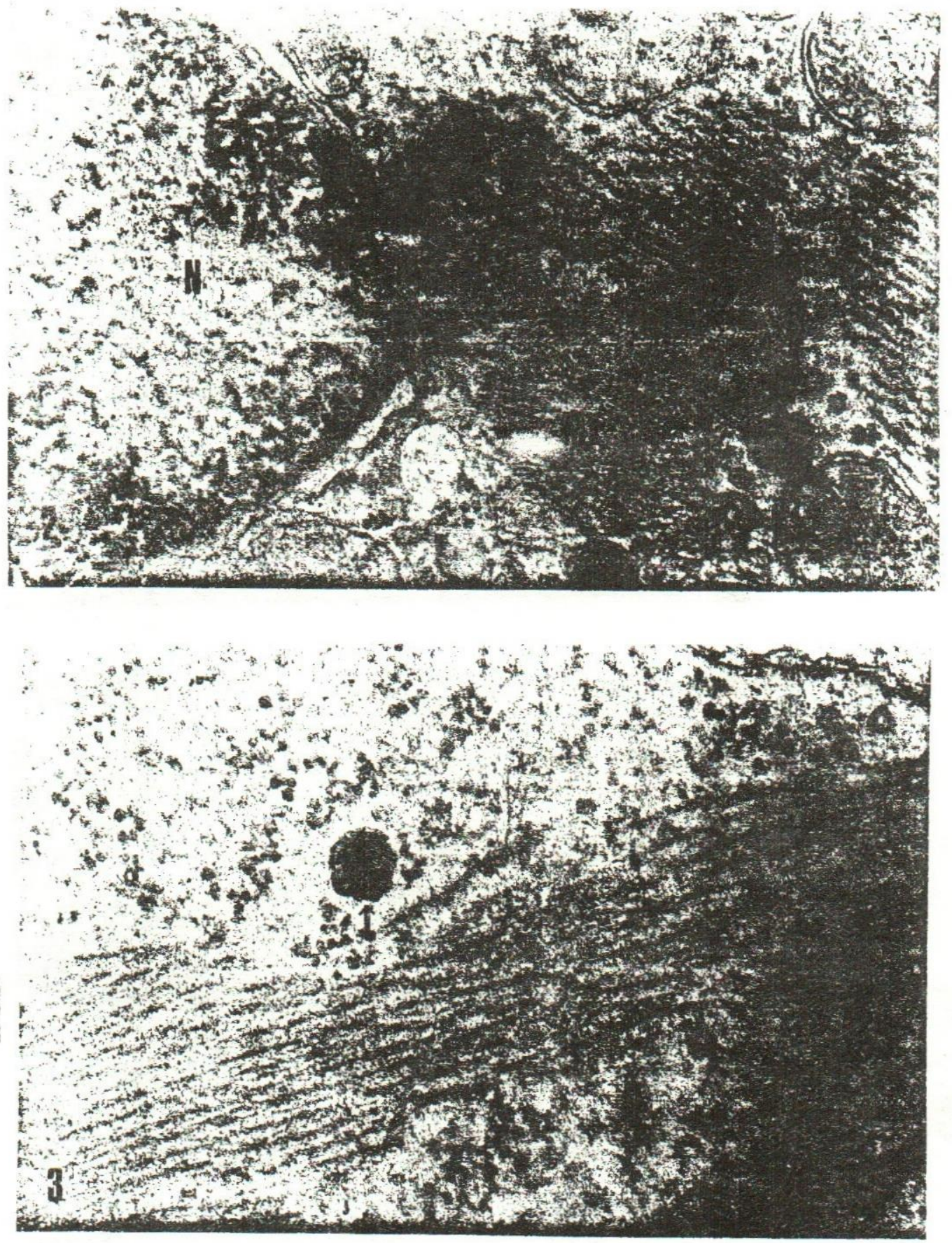


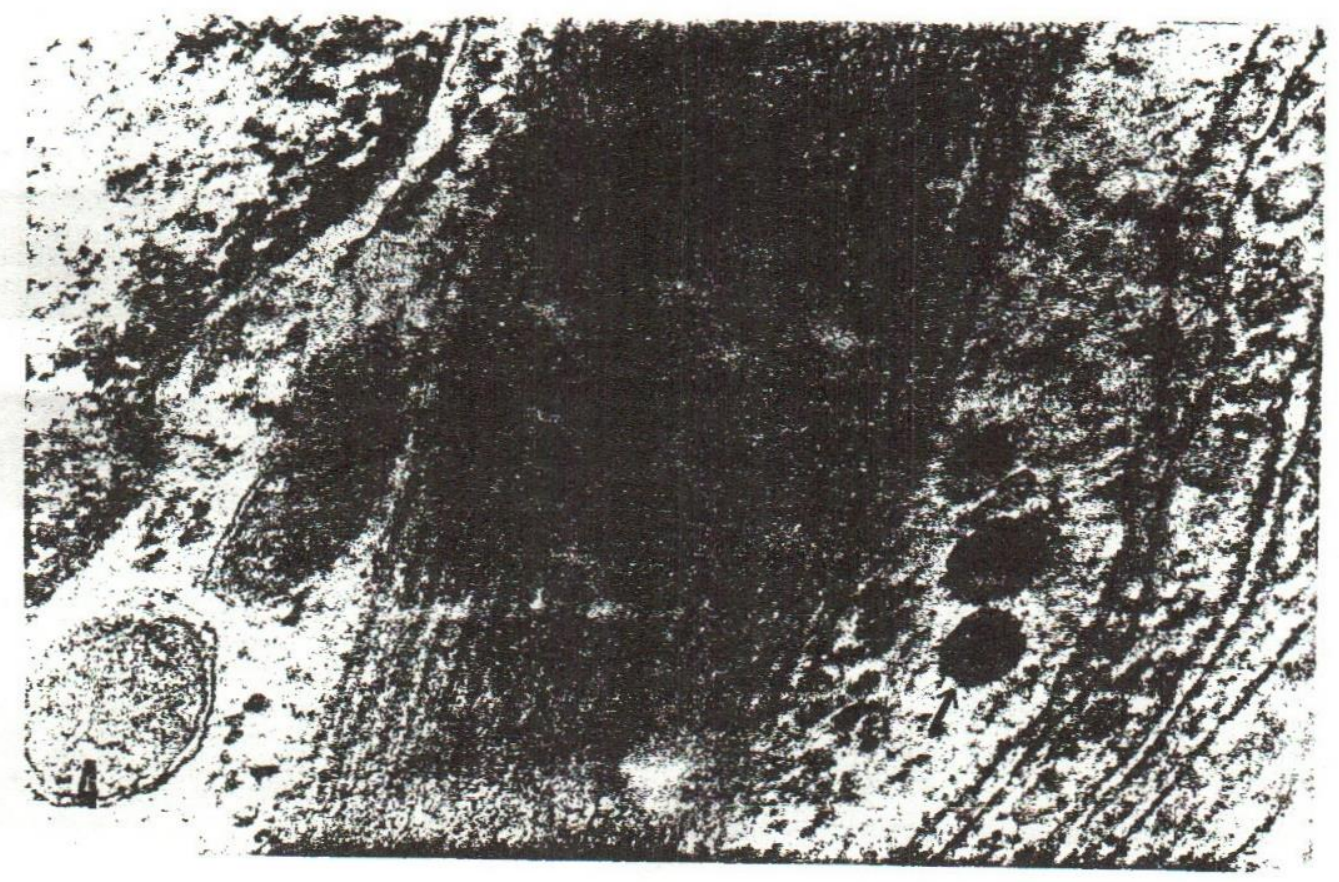

$\begin{array}{ll}4 & \end{array}$

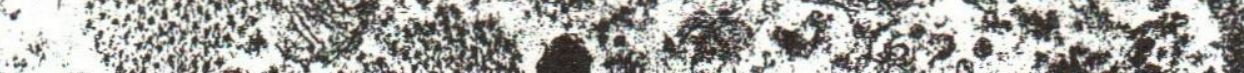

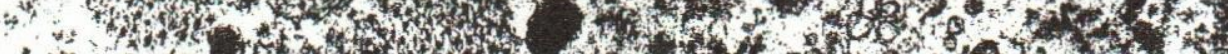

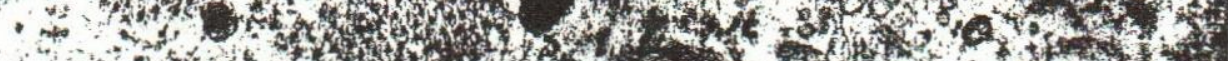

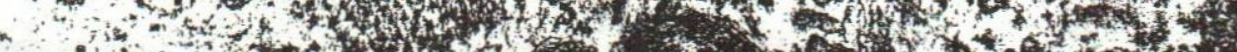

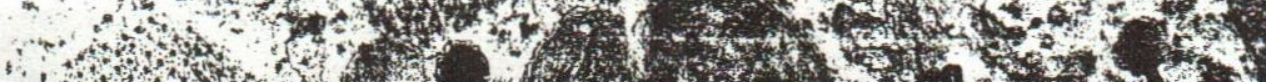

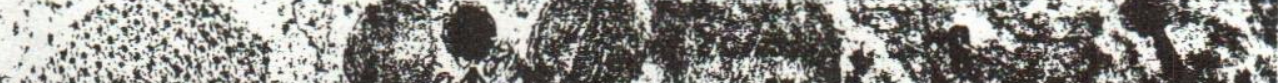

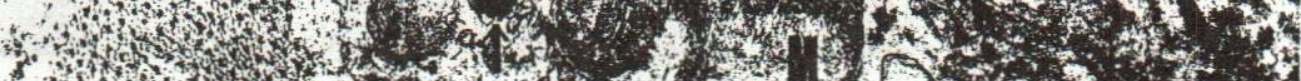
1. 70 .

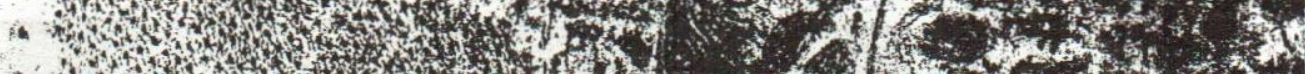

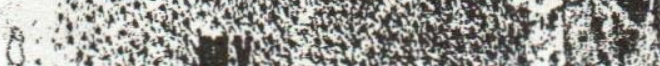

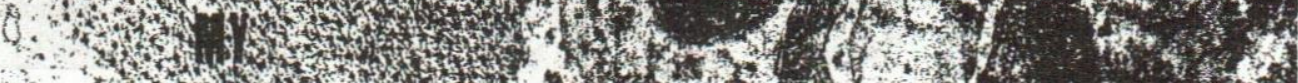
4.

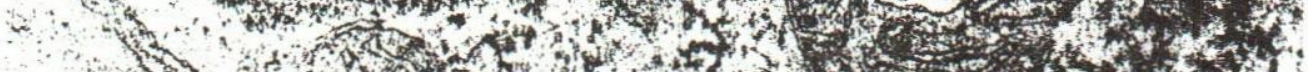

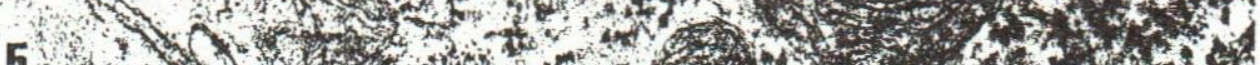

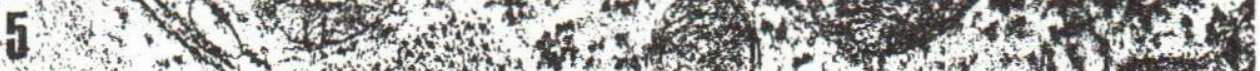

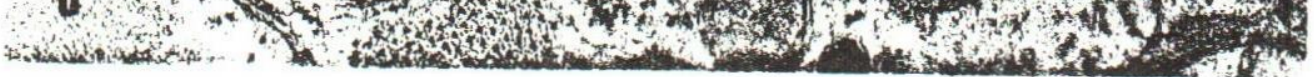



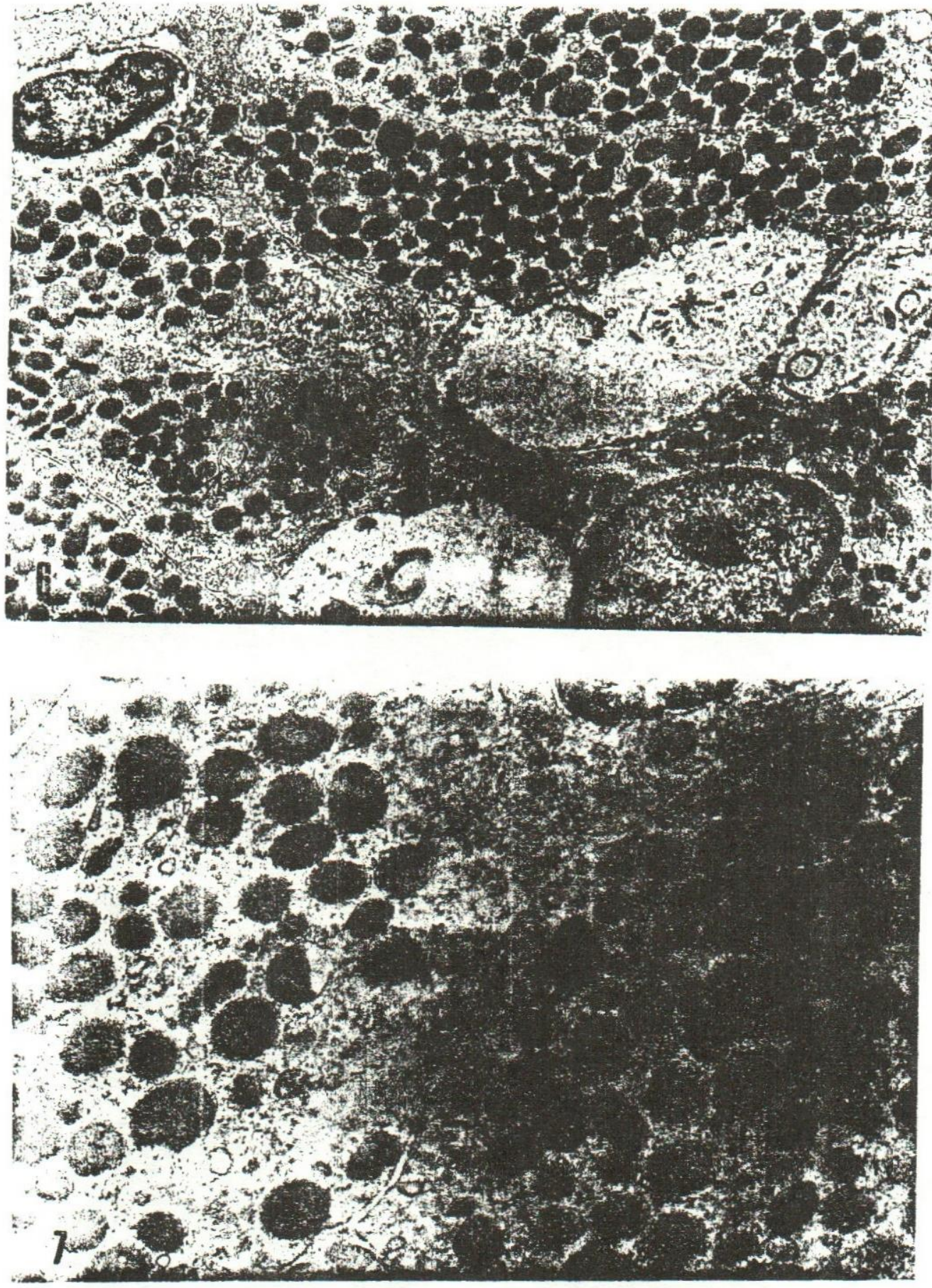

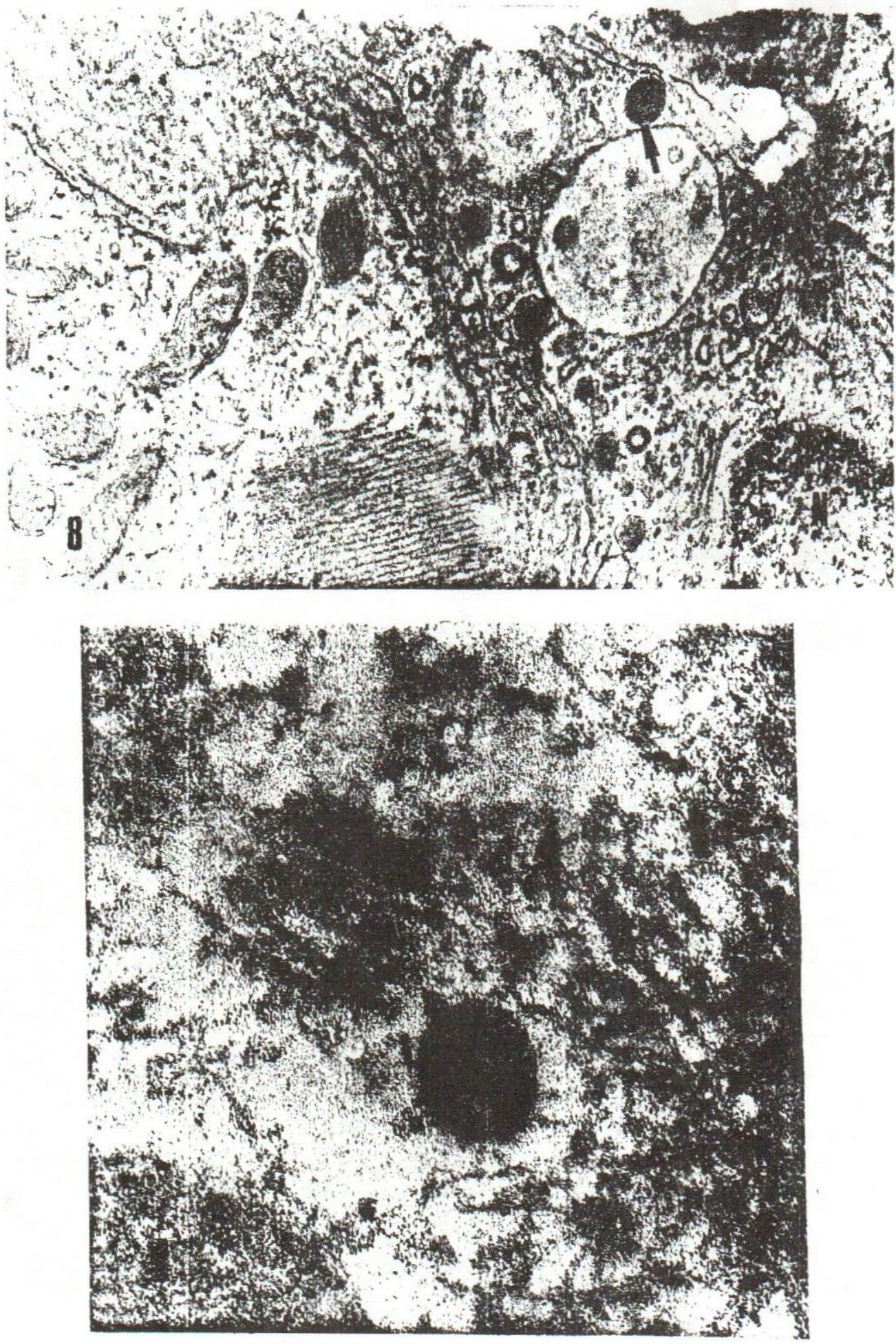